\title{
Kvalitetsfremmende praksis i arbeidet med de grunnleggende ferdighetene
}

Av Anne Karin Rudjord Unneland, førstelektor em, NLA Høgskolen

\section{Abstrakt}

Grunnleggende ferdigheter som begrep ble innført i grunnopplæringen i Norge med læreplanreformen Kunnskapsløftet i 2006. De fem grunnleggende ferdighetene å lese, å skrive, å regne, muntlige ferdigheter, og digitale ferdigheter skal utvikles som fellesoppgave for alle fag i skolen. Forskning viser at det er ulike forståelser av begrepet grunnleggende ferdigheter og at mange lærere tenker i kategorien elementære ferdigheter og at det handler om å lære inn en ferdighet. Det kan være grunn til å anta at ferdighetsbegrepet langsomt er blitt utarmet i vår moderne tid. Kanskje er det slik at fordi det praktiske og håndverksmessige er blitt devaluert de siste tiår, mangler lærere en dyp forstålse av hvordan ferdigheter læres og videreutvikles, og hvilke tenkemåter som kan utvide forstålsen av ferdigheter.

Formålet med artikkelen er å bidra i en diskusjon om hva som kan forsterke trangen og viljen til å forbedre ferdigheter. Artikkelen reflekterer over hvordan kvaliteten kan fremmes i utvikling av grunnleggende ferdigheter $i$ skolesammenheng. Teksten drøfter dette spørsmålet med utgangspunkt i teori fra mesterlæretradisjonen. Perspektivene utvides ved teoretikere som Richard Sennett, Donald Schön og Aristoteles. Det ble tydelig i litteraturstudien at klasserommet som et lærende fellesskap med lærere som gir innsatsen og resultatene verdi, er av stor betydning. Kvalitet kan fremmes gjennom refleksjon og en systematisk og gjennomtenkt tilbakemeldingskultur, der det å gjøre feil 
ses på som en hjelp til mer læring og ikke minst at det i klassefellesskapet verdsettes og gis rom for forskjellighet, ulike mål og ulike mestringsnivåer.

Nøkkelord: Ferdighet, ferdighetslæring, progresjon, kvalitetsutvikling, mestertradisjon

\section{Abstract}

Essential skills as a concept were introduced in basic education in Norway with the curriculum reform «Kunnskapsløftet» in 2006. The five basic skills of reading, writing, numeracy, spoken language skills and digital skills should be developed as common background for all school subjects. Research shows that there are different understandings of the concept essential skills and that many teachers believe this means elementary skills and that it just concerns skill training. There may be reasons to assume that the concept of skill has slowly been depleted in our modern era. Perhaps this is the case because the practical and craftsman-like side of things has been devaluate in recent decades, and teachers lack a deep understanding of how skills are learned and further developed, and of which ways of thinking can expand the understanding of the concept of skills.

The purpose of the article is to contribute into a discussion about what can reinforce the urge and willingness to improve skills. The article reflects on how quality can be promoted in the development of essential skills in the school context. The text discourses on the question based on theory from the mastery learning tradition. The perspective is expanded by theorists such as Richard Sennett, Donald Schön and Aristotle. It is apparent from the literature study that the classroom as a learning community with teachers who appreciate both the effort and the results, is of great importance. Quality can be promoted through reflection and a systematic and thoughtful feedback culture, where making mistakes is seen as a help for more learning and not least that in the class-community diversity, different goals and different levels of mastery are valued and given space.

Key words: Skill, skill learning, progression, quality development, mastery tradition 


\section{Innledning}

Skolen har som oppgave å fremme læring og danning gjennom planlagte og systematiske aktiviteter. En lang læreplantradisjon i norsk skole har formulert læringsmål i form av kunnskap, ferdigheter og holdninger. I læreplanverket for Kunnskapsløftet, 2006 (LK 06) ble dette endret til kompetansemål, og fem grunnleggende ferdigheter ble integrert i kompetansemålene til skolefagene. De fem grunnleggende ferdigheter er digitale ferdigheter, muntlige ferdigheter, å kunne lese, å kunne regne og å kunne skrive. Dette betraktes som nødvendige redskaper for læring og faglig forståelse, og elevene skal gjennom arbeid med skolefagene tilegne seg disse grunnleggende ferdighetene (Pedlex, 2017, s. 169).

Det kan stilles ulike spørsmål knyttet til læreplanens innføring av grunnleggende ferdigheter. Mange har hevdet at det er vesentlige mangler ved utvelgelsen av ferdigheter. Særlig er det uttrykt bekymring fordi hverken sosiale ferdigheter, estetiske ferdigheter eller ferdigheter til kritisk tenkning er tatt med som grunnleggende ferdighet. Fremtidens skole (NOU 2015, s. 8) anbefalte en reformulering av de fem grunnleggende ferdigheter fordi utvalget mente at begrepet grunnleggende ferdighet kommuniserte en smalere forståelse enn ønsket. Utdanningsdirektoratet informerer på sine nettsider om at i den nye læreplanreformen kalt Fagfornyelsen skal de grunnleggende ferdigheter videreføres, men ansvaret for dem skal tydeliggjøres (Udir., 2019).

Ferdighetslæring er fortsatt en sentral del av skolens virksomhet. Derfor er det både aktuelt og relevant å utforske hvordan ferdigheter læres, hva som kan svekke ferdighetslæring, og hva som kan fremme kvalitet i ferdigheter. Hovedsporsmälet $i$ denne artikkelen er hvordan kvalitet kan fremmes $i$ utviklingen av grunnleggende ferdigheter $i$ skolesammenheng. Å lære å videreutvikle ferdigheter har vært et sentralt tema innenfor både mesterlære-tradisjonen (Nielsen og Kvale, 1999, 2003) og teori om læring som del av sosial praksis (Lave og Wenger, 2003). Artikkelen drøfter ferdighetsbegrepet med utgangspunkt i disse teoriperspektivene. Både Aristoteles' (1999) og Richard Sennetts' (2009) innsikt knyttet til ferdighetslæring blir presentert. Refleksjon utdypes gjennom Donald Schöns (1983) teori. Artikkelen baserer seg på litteraturstudie, og kildene er valgt ut med bakgrunn i søkeordene ferdighet, 
ferdighetslæring og kvalitetsutvikling. Første del av artikkelen gjør kort rede for teori om mesterlæretenkning og læring som del av sosial praksis. Deretter utdypes Aristoteles' techne-begrep (1999) og Sennetts' (2009) perspektiv på ferdighetsutvikling, og hva som kan øke trangen og engasjementet til stadig å bli bedre. Til slutt beskrives refleksjon gjennom Schöns (1983, 1987) begrep reflection-on-practice og reflection-in-practice. Med bakgrunn i disse kildene ønsker forfatteren å drøfte og bidra med nye perspektiv på hva som kan fremme kvalitetsutvikling i de grunnleggende ferdigheter, og slik sett hva som kan stimulere elever til å videreutvikle sine ferdigheter.

\section{Aktuell forskning}

I forbindelse med evaluering av Kunnskapsløftet, 2006 2012, var grunnleggende ferdigheter et av evalueringens fokusområder (Hodgson, Rønning, og Tomlinson, 2012). Rapporten viser at lærerne stor sett er positive når det gjelder læreplanens fokus på de fem grunnleggende ferdigheter. Støtten er særlig sterk blant lærere på barnetrinnet, mens lærere i videregående opplæring ikke i samme grad gir sin tilslutning. Det kan se ut til at lærere i videregående skole tenker $\mathrm{i}$ kategorien elementære ferdigheter som skal mestres i begynneropplæring eller på lavere trinn og derfor ikke har relevans på høyere trinn i opplæringen (Hodgson, Rønning og Tomlinson, 2012). Arbeid med for eksempel leseferdigheter utover begynneropplæring er oftest knyttet til elever som sliter med lesing, og ferdigheter forstås som ferdiglært når man mestrer.

Dale og Øzerk (2009) finner at arbeidet med grunnleggende ferdigheter blir prioritert svært forskjellig i ulike kommuner og fylkeskommuner. I sluttrapporten fra evalueringen av Kunnskapsløftet (Dale, Engelsen og Karseth, 2011) konkluderte forskerne med at læreplanen ikke på en god nok måte synliggjør progresjon gjennom utdanningsløpet i arbeidet med de grunnleggende ferdigheter. I en spørreundersøkelse fra 2015 svarte under halvparten av skolelederne og skoleeierne at skolene i stor grad hadde etablert en felles forstålse av hva grunnleggende ferdigheter innebar (Gjerustad, Waagene og Salvanes, 2015). Undersøkelsen viste også at det systematiske arbeidet med ferdigheter varierer sterkt, og at det fortsatt var uklart for mange av aktørene 
i skolen hva det betyr å arbeide med grunnleggende ferdigheter. Rødnes og Gilje (2018) konkluderer i sin forskning med at det er en viktig oppgave for lærere å se til at «forståelsen av grunnleggende ferdigheter bli tydeliggjort ... ikke minst - for elever» (Rødnes og Gilje, 2018, s. 210).

I 2017 lanserte Kunnskapsdepartementet læreplanreformen Strategi for fagfornyelse. Meld. St. 28 (2015-2016) Fag - Fordypning - Forståelse. I den forbindelse blir det understreket at hovedprinsippene fra Kunnskapsløftet skal ligge fast. Læreplanene skal fortsatt benytte begrepet kompetansemål, og elevenes utvikling av grunnleggende ferdigheter skal fremdeles stå sentralt i opplæringen.

Oppsummert kan vi si at læreplanen fastslår at grunnleggende ferdigheter er en viktig forutsetning for læring og at disse ferdighetene skal videreutvikles. På den annen side er det uklart for mange av aktørene i skolen hva det å arbeide med grunnleggende ferdigheter betyr. Selve begrepet ferdighet kan lede oss til å tenke at det er noe vi blir ferdig med, et slags minstekrav eller en teknikk som skal læres en gang for alle (Hertzberg, 2012). I skolesammenheng kan både vektlegging av nye begrep som læringsutbytte og kompetansemål, men også vektlegging av effektivitet, ha tatt oppmerksomhet fra det mer langsomme arbeidet med ferdigheter. På den annen side ser vi interessante tendenser som peker mot fornyet verdsetting av ferdigheter. Ulike TV-kanaler byr på ganske så praktiske reality-serier som Anno og Symesterskapet, der nettopp ferdighetene er helt avgjørende.

På denne bakgrunn er det både relevant og aktuelt å styrke og å utvide vår forståelse av begrepet ferdighet og drøfte hvordan det i skolesammenheng kan arbeides med å fremme kvalitet i utvikling av ferdigheter.

\section{Ferdigheter og mesterlære}

Mesterlæretradisjonen har en lang historie, og dens opprinnelse finnes i middelalderens håndverkslaug. Laug betyr fellesskap eller organisme og knytter derfor mesterlære til håndverksfellesskap (Kvale, 2003, s. 273). Sigurjonsson (2003) som har forsket på praktisk læring i danske «erhvervsuddannelser», viser til at mesterlæretanken i utdanningssammenheng gjentatte ganger er blitt utfordret og nedprioritert, men likevel stadig har dukket opp igjen. 
Kvale har i kapitlet En promoderne mesterlare i et postmoderne samfund argumentert for mesterlærens fornyede aktualitet. Han hevder at mesterlærelignende former for integrasjon av arbeid og læring er nødvendig i det postmoderne samfunn, og han henviser særlig til kravene om livslang læring, fleksibel læring og læringsfellesskap (Kvale, 2003). Han synes å se økt respekt for praktisk kunnskap og medlæring som finner sted gjennom deltagelse i fellesskap og uttaler at «mesterlærelignende praksisfællesskaber kan tjene som oaser for mening og samhørighed med mulighed for at etablere fælles værdier og nære identitetsmæssige tilhørsforhold i et ellers uoverskuelig og hurtigtforandret større samfund» (Kvale, 2003, s. 301). Hvilke tanker knyttet til mesterlære kan det være aktuelt å trekke inn i en samtale om dagens skole og ferdighetslæring?

Å observere det andre gjør er av stor betydning ifølge mesterlære (Nielsen og Kvale, 1999). Det ligger en progresjonstenkning bak svennenes opplæringsløp, der de først lærer observasjonsoppmerksomhet ved å se seg om og se på hva andre gjør. Svennene lærer at de er avhengig av hverandre i verkstedet, og de oppdager hvordan ferdigheter, kunnskap og holdninger kan inngå i deres yrkesmessige framtid (Nielsen og Kvale, 2003). Gjennom å observere mestrenes glede og engasjement i verkstedet får de forbilder og rollemodeller i læringssituasjonen. Svennene observerer, øver, imiterer, prøver og korrigeres systematisk i læringsprosessen. Mesterlære oppfordrer til prøving og feiling og framhever at det å feile er en mulighet til å lære. Mesterlære understreker det å lære gjennom egne erfaringer, men peker også på den betydning og konsekvens som andres handlinger gir (Kvale, 2003). Deltagernes erfaringer gir en mangfoldighet som er vesentlig i et verksted. Der hvor det er «forskelligartede deltagere til stede, skaber ofte de bedste læringssammenhænge» (Kvale, 2003 s. 303).

En mester må våge å se etter nye løsninger på utfordringer. Som ekspert handler det ikke bare om å repetere, men også å forbedre, derfor er kreativitet en kvalitet ved gode mestre. Mesterlære understreker at læring skjer gjennom å arbeide med stadig mer komplekse arbeidsoppgaver (Saugstad, 2003), men at arbeid som er rotfestet i det velkjente, i rutiner og tradisjoner og vaner har en positiv virkning på læring (Nielsen og Kvale, 2003). Et viktig aspekt i verkstedet er også at «Det man gjør blir fylt med betydning og alvor» (Nielsen 
og Kvale 1999, s. 168), og dette er en forutsetning for at arbeidet i verkstedet skal holde kvalitet.

En del av kritikken som retter seg mot mesterlære er at det er en autoritær og konserverende utdanningstilnærming, og at den ikke sikrer nødvendig teoretisk innsikt. Kritikere har også påpekt at den nye interesse for mesterlære; «... er en nyromantisk drøm uden bund i virkeligheden» (Illeris, 2000, s.143). Mesterlære er ofte blitt framstilt som imitasjon og modellinnlæring gjennom en enkel og assimilativ overtakelse av tradisjon, men dette prøver Kvale og Nielsen (2003) å nyansere ved å vise til de ressurser som vi kan hente ut fra det å lære i praksis. I vår sammenheng vil vi ikke drøfte mesterlære som idé, men vi vil hente ut perspektiv som kan være utvidende for vår forståelse av ferdighetslæring.

\section{Ferdigheter og techne}

Allerede i antikken skriver Aristoteles om ulike kunnskapsformer i Den nikomakiske etikk (1999)). Han foreslår begrepet techne om det som omfatter ferdigheter. Aristoteles' begrep techne sammenholder innsikt og praktiske ferdigheter, og han sier at techne foredles i veksling mellom tenkning og handling. Kvaliteten styrkes ikke bare gjennom å gjenta, men gjennom å fornemme og anvende med en klar intensjon om forbedring (Ramirez, 1995). Det er en forskjell i innstilling om vi søker å mestre en ferdighet, så å si bli ferdig med innlæringen, eller om vi drives mot å utvikle og forbedre kvaliteten i ferdigheten, slik for eksempel store musikere gjør. Techne slik Aristoteles utlegger det har en kunnskap knyttet til ferdigheter, og denne kunnskapen har muligheter i seg til stadig å bli dypere og mer solid.

Filosofen Martha Nussbaum (Brunstad, 2007) hevder at et kjennetegn ved høy techne-kvalitet er evnen til å forutse konsekvenser og resultat. Det er en viten innebygd i våre ferdigheter selv om vi ikke alltid klarer å uttrykke det med ord. Øvelse er ikke tilstrekkelig. Ferdigheter videreutvikles gjennom dialog og gjennom å styrke evnen til å vurdere konsekvenser og fornemme kvalitet. Eikeland minner oss om at ordet skole kan stamme fra det gammelgreske ordet skholê som betegnet «et pauserom - en refleksiv, dialogisk møteplass - innfelt i praktiske sammenhenger» (Eikeland, 2014, s. 384). 


\section{Ferdigheter og refleksjon}

Donald Schön (1983) har forsket på yrkesutøveres kunnskap og kompetanse, og hvilken rolle refleksjon kan ha. Schön peker på at dyktige praktikere ikke bare kjennetegnes av sin evne til å løse problemer, men like mye av sin evne til å oppdage og analysere disse. Å reflektere forbindes ofte med noe vi gjør etter at vi har utført en handling. Refleksjon skal bidra til at erfaringene kan rekonstrueres, og at man kan lære av det man gjør. Schön (1983) hevder at i tillegg til refleksjon etter eller over handling (on-action), så vil refleksjon i handling (in-action) ha en viktig funksjon. Hva som skjer i utførelsen av ferdigheter er vanskelig å forklare fordi det er en kunnskap som kommer til syne i handlingen. Schön (1987, s. 22) refererer, i tillegg til Polanyi’s begrep taus kunnskap og til Raymond M. Hainer som har uttalt «Knowing more than we can say». Det er det Schön legger i sitt begrep knowing-in-action. Vi vet hva og hvordan vi skal handle i situasjonen, men det vil være vanskelig for oss å forklare det. Kunnskapen ligger i, og kommer til syne i handlingen (Schön, 1987).

Schön (1987) utdyper refleksjonsbegrepet knyttet til hvordan vi opptrer når en situasjon ikke er normal eller som forventet. Han kaller det for «experience of surprise». Schön viser til to måter å utøve slik refleksjon på. Vi kan for eksempel reflektere «on-action». Dersom vi i handlingen reflekterer «onaction», tenker vi tilbake på handlingen for å se om vi kan oppdage hva som kan ha bidratt til den uventede situasjonen eller overraskelsen. Dette er noe vi foretar oss ved å stoppe opp og ta en pause, og reflektere over handlingsforløpet. Refleksjon på denne måten har ingen påvirkning på handlingen, vi bare reflekterer over den (Schön, 1987). «Reflection-in-action» foregår uten at vi nødvendigvis stopper opp i situasjonen. Vi reflekterer i handlingen, uten å avbryte det vi holder på med. På den måten bruker vi refleksjonen til å utarbeide noen strategier som kan hjelpe oss videre. Nye strategier kan også skape overraskelser, eller problemer, og vi må kanskje reflektere videre over hvordan vi skal handle (Schön, 1987).

Dale (1989) snakker om menneskets refleksive intelligens. Refleksjonen gjør oss i stand til å bearbeide erfaringer, og oppdage meninger ved situasjoner, som så får betydning for vår handling. Refleksjonen blir også viktig dersom vi ønsker å se det karakteristiske ved en ferdighet som vi kan ta med oss videre. 


\section{Ferdigheter mellom praksis og fantasi}

Ferdigheter har historisk sett ofte vært knyttet til verksted og ulike håndverkstradisjoner. Sosiologen Richard Sennett (2009) prøver å forstå hvordan folk blir praktisk engasjert uten at det nødvendigvis blir instrumentelt. Da det håndverksmessige fikk mindre å bety etter industrisamfunnets framvekst, ble ferdigheter gradvis mer betraktet som noe elementært og med lavere status. Ferdigheter ble oppfattet som øvelse og teknikk, frikoblet tenkning og refleksjon. Han framholder at «håndværksmæssighed er udtryk for en varig, grundlæggende menneskelig impuls - ønsket om at gøre arbejdet godt for dets egen skyld» (Sennett, 2009, s. 18). Sennett beskriver i boka The Craftsman (2008) (oversatt til dansk, Håndværkeren, 2009) arbeidets historie. Han uttaler at «Historien har skabt brudlinjer mellem praksis og teori, teknik og udtryk, håndværker og kunstner, skaber og bruger, og det moderne samfund lider under denne historiske arv» (Sennett, 2009, s. 21). Fordi praksis, det praktiske og håndverksmessige er blitt devaluert i mange tiår, savnes en dypere forståelse av hvordan ferdigheter læres og videreutvikles, og hvilke tenkemåter som kan utvide forståelsen av ferdigheter. Evnen til å framstille noe godt $\mathrm{i}$ et håndverksperspektiv er kanskje bleknet, hevder Sennett (2009), men det er likevel noen viktige dimensjoner knyttet til håndverk som det er verd å utforske.

Håndverk, verksted, verktøy, materiale og teknikk forbindes med ferdigheter, men Sennett legger til at også tenkning og følelse rommes i framstillingsprosessen (Sennett, 2009, s. 17). Ferdighetene kan ikke isoleres. Ferdigheter er ikke bare ferdigheter. Ferdigheter er både å gjøre og å skape. Han understreker den nære forbindelse mellom hode og hånd og hevder at en dialog mellom en konkret praksis og egen tenkning kan skape en rytme mellom problemløsning og problemavdekking som fremmer kvalitet. Undersøkelser viser at jo høyere ferdighetsnivået er, jo mer problemorientert blir ferdighetene (Sennett, 2009, s. 30). Gjennom gjentagelse, innsikt, fornemmelser, dialog og selviakttagelse så oppdages problemer som har kraft i seg til å drive en ferdighet framover. «En god håndværker fører en dialog mellem en konkret praksis og sin tænkning» (Sennett, 2009, s.19). Samtidig vil det på et høyt ferdighetsnivå være mye taus viten. Han hevder at taus viten fungerer som et anker, mens eksplisitt bevissthet fungerer som kritikk og kor- 
rektiv. Kvalitetsutvikling i ferdigheter er slik sett avhengig både av taus og språklig bearbeiding.

Ferdigheter springer ut av kroppslige praksiser, av å gjøre, men det oppstår samtidig en kunnskap om det vi gjør slik både Aristoteles og Polanyi påpeker. Denne forståelsen eller kunnskapen kan videreutvikles ved hjelp av fantasien, språket og forventninger. $\AA$ utvikle og forbedre ferdigheter er arbeidsomt, og derfor må engasjementet vekkes. Ferdighetsutvikling avhenger av hvordan gjentagelsen organiseres og må balanseres med konsentrasjonsmuligheter. Jo bedre teknikk, jo lengre kan man holde ut å øve, men det er samtidig viktig hvordan gjentagelser organiseres.

Sennett (2009) uttaler at det som kan true ferdighetslæring er fragmentering, og det som kan styrke er terping og rutiner. Samtidig påpeker han at faste mål vil begrense, og åpne mål vil drive videre. Sentralt er også evnen til å forestille seg. For å forutsi konsekvenser og resultater er nettopp evnen til å forestille seg sentral. Det kan styrkes av å leke med mulighetene og være nysgjerrig. Fantasi og forestillingsevne kan styrke ferdighetsinnlæring. Terping og øvelse må derfor settes inn i et skapende mulighetsrom.

Engasjement og opplevelse av mening sammen med mestring av ferdigheter vil øke evnen til å konsentrere seg. Det å gjenta og å lære av gjentagelsen er stimulerende. Det ser vi tydelig både i barns lek, og vi aner det hos dem som spiller et instrument. Fiolinisten teller ikke antall ganger hun spiller en sekvens. Hun vil gjenta den for å forbedre, men også bare for å kunne gjenta den, hevder Sennett (2009). Det samme ser vi i barns lek.

\section{A utvikle en ferdighet}

I skolesammenheng kan vi ta eksempelet å utvikle leseferdighet. Først handler det om å lære lesekoden, men ettersom elevens leseferdighet øker, så kan det dannes og utvikles en innsikt eller kunnskap om lesingen. Eleven kan snakke om sin egen lesing og vurdere dens brukbarhet i forskjellige sammenhenger og overfor ulike oppgaver. Det er ikke bare en teknisk ferdighet å lese, men det er også en kunnskap knyttet til det å lese. Det er dette Aristoteles poengterer og kaller techne-kunnskap.

I de senere år er det blitt «mer vanlig å bruke mester-lærling-relasjonen som 'bilde’ på gode læringssituasjoner» (Lauvås og Handal, 2000, s. 57). I 
et lærende fellesskap vil læring avhenge av forholdet mellom de muligheter elevene får adgang til og de begrensninger som gis (Lauvås og Handal, 2000, s. 59). I en skolekontekst kan vi reflektere over hvilke signaler elevene møter i «verkstedet» gjennom rutiner, oppgaver, læringsmiljø og lærerrollen, og hva slags respons medlemmene av fellesskapet gir hverandre. Videre kan vi undersøke hvordan elevene stimuleres til å sette ord på det de gjør og hvilke samhandlinger, samtaler og refleksjoner som foregår.

Mesterlæreperspektivet forstår ferdigheter som trinn på veien til noe større, og fellesskapet ses som en læringsressurs. Det å se på og observere andres aktivitet og gjennomføring anses som læringsfremmende fordi læring blir til «gennom eksemplets magt» (Kvale, 2003, s. 302). Øvelse er en sentral læringsaktivitet innenfor ferdighetsutvikling, gjerne sammen med vektlegging av en fellesskapsorientert måte å lære på. For å gjøre ferdighetene mer brukbare, må innsikt og situasjonsfornemmelse knyttet til konkrete situasjoner oppdages og analyseres. Ferdigheter er derfor ikke bare det å kunne gjøre noe. For å øke kvaliteten må det foregå en tankevirksomhet og refleksjon knyttet til handlingene. Gjennom øvelse og gjentagelse vokser ferdigheten fram, vikles ut så å si, og gjennom å studere, artikulere, og kritisk vurdere kan ferdigheter bli mer og mer kyndige (Eikeland, 2014, s. 383).

Et personlig eksempel som kan illustrere dette. Konfirmantene skulle lese bønner på gudstjenesten og kom i 10-tida for å øve. Tilfeldigvis var dagens klokker pedagog. Hun begynte å samtale med dem om det å lese høyt for andre, hvilken verdi de selv så i oppgaven, hva de tenkte på når de hørte andre lese høyt, og hva de ønsket resultatet skulle bli. Det utviklet seg til en spennende samtale og en entusiastisk øvingsaktivitet. Og resultatet? Bedre enn noen gang! Konfirmantene leste høyt og tydelig. Og de oppdaget at de ble mye tryggere.

I mesterlæretilnærming blir deltagelse verdsatt, og gjennom denne verdsettingen vil konsentrasjon og utholdenhet styrkes. Ferdighetsinnlæring som blir fragmentert og individualisert vil ikke ha den samme drivkraften. Det er praksisfellesskapet med både mester og andre deltagere som hjelper den lærende til å holde aktivitet og motivasjon oppe til å forbedre ferdigheter. Kvale hevder også at mangfoldighet er vesentlig, og læringsmiljøer hvor det er «forskelligartede deltagere til stede, skaber ofte de bedste læringssammenhænge» (Kvale, 2003 s. 303). 
Selv om vi i noen grad kan analysere ferdigheter og finne fram til deler som bygger opp en ferdighet for eksempel i forbindelse med lesing, så oppdager vi at det er mye som det ikke så lett kan settes ord på. Polanyi (1966, 2000) er kjent for å ha introdusert den tause dimensjonen i vitenskapsfilosofisk sammenheng. "Tacit knowing» omfatter slik han uttrykker seg både «det å kunne noe, vite noe, kjenne igjen noe og å bruke verktøy» (Polanyi, 2000, s. 14). Dette kan være vanskelig å artikulere. Likevel er det et mål å utforske og prøve å beskrive. Schön poengterer det samme når han skriver om reflection-in-action. Det kan kanskje best forstås som en holdning som kan utvikles knyttet til handlinger eller ferdigheter. Det innebærer en språklig bearbeiding av handlingen eller ferdigheten som gode lærere kan stimulere hos sine elever. Anstrengelser med å sammenligne, sette ord på, gjerne med metaforer eller bilder, kan styrke læring av ferdigheter og holde i gang et ønske om kvalitet.

For å få elever til å streve etter kvalitet må det også føres noen skapende aspekter inn i utviklingen av ferdigheter. Dewey hevder at «Arbejde, der hele tiden gennemsyres af den legende holdning, bliver til kunst» (sitert i Sennett, 2009, s. 289), og Sennett hevder at godt håndverksmessig arbeid er avhengig av nysgjerrighet.

\section{Ferdigheter og kvalitet}

I håndverkslaugene la gode håndverkere vekt på å skape kvalitet, og de utførte et godt stykke arbeid for fellesskapets skyld. Normene ble fastsatt i fellesskapet og ble overgitt nye generasjoner i stadig forbedret utgave. Verkstedets prosesser og ordninger var sentrale (Kvale, 2003). Sennett definerer det moderne verkstedet som «Et produktivt rum, hvor folk forholder sig ansigt til ansigt til autoritetsmæssige spørsmål» (Sennett, 2009, s. 64). I rommet er det en mester som har autoritet fordi han kjenner ferdighetene og derfor leder fastsetting av normene. I et verksted vil det være en spenning mellom autoritet og autonomi. I klasserommet må læreren ha en slik autoritet, og være en som fastsetter normene og leder opplæringen, men autoriteten bygger på hennes ferdigheters kvalitet, og at hun ser hva andre ikke ser og vet hva andre ikke vet. 
Arbeid med ferdigheter må trekkes inn i fellesskapets dialogiske rom, og må ikke isoleres i instruksjon og repetisjon. Ifølge Schön (1987) kan refleksjon med stor fordel knyttes til «experience of surprise». Dette kan vi lett overføre til elevers arbeid med utvikling av ferdigheter. Systematikk og opplæring i å reflektere «on-action» kan hjelpe elevene med å tenke tilbake på handlingen for å se om de kan oppdage hva som har bidratt til forbedring eller det uventede. Refleksjon på denne måten har ingen påvirkning på handlingen, men eleven kan oppøve det å se det karakteristiske ved en ferdighet som kanskje kan tas med videre (Dale, 1989). «Reflection-in-action» foregår slik Schön (1987) forstår det uten at vi nødvendigvis stopper opp i situasjonen. Vi reflekterer i handlingen, uten å avbryte det vi holder på med. På den måten bruker vi refleksjonen til å utarbeide strategier som kan hjelpe oss videre i prosessen. Dette kan lærere stimulere til og bevisstgjøre sammen med sine elever, for at de skal bruke det som drivkraft til kvalitet.

Gode verksteder eller klasserom har limt mennesker sammen gjennom arbeidsmessige ritualer der evnen til imitasjon og kopiering oppmuntres, og etter hvert utvikles det selvstendighet og egenart (Kvale, 2003). Forskjellen mellom etterligning av en prosedyre eller en ferdighet og en bredere forståelse av hvordan man kan bruke den, er nettopp et kjennetegn ved økt ferdighetsutvikling (Sennett, 2009). Læreren har en sentral rolle når det gjelder å skape forståelse for og balanse mellom struktur og selvstendighet. For å få høy kvalitet i en ferdighet behøves frihet, men friheten hviler på en utholdenhet og engasjement knyttet til gjentagelse og struktur.

Stolthet er også et aspekt ved kvalitet i håndverksammenheng. Håndverkere føler mest stolthet over ferdigheter som modnes (Sennett, 2009). Fornemmelse av stolthet trenger ikke svekkes av det å gjøre feil, men kan svekkes av konkurransepress og rangering, hevder han. Ferdigheter er basert på en langsom innlæringsprosess og på faste arbeidsvaner. For gode håndverkere er rutiner ikke statiske, de utvikler seg stadig. Denne utviklingen omfatter også det å prøve og feile. Å måtte gjøre feil for siden å gjøre det mer rett, er en allmenn erfaring. Vi blir mer trygge når vi selv oppdager feil. Når vi så får til noe flere ganger, blir vi enda tryggere. Gode læringssituasjoner oppøver den lærende til å se positivt på det som er feil og ikke minst på det å oppdage feil. Lærere må være oppmerksom på hvordan deres vurderingspraksis kan virke hemmende når det gjelder å videreutvikle kvalitet. Dersom 
elever opplever at feilene kommer i fokus på en slik måte at de gir «dårlige karakterer», kan elever venne seg til å gjenta det rette, istedenfor å våge å utforske forbedringer.

\section{Drivkraft til kvalitet}

Sennett er opptatt av hva som stimulerer ambisjonen til å gjøre noe godt innen håndverk. Han sier at det er motivasjon og trang til kvalitet som avgjør mer enn evner, og han leter etter sosiale forhold som former motivasjonsfaktorene (Sennett, 2009, s. 243). Kvale (2003) påpeker at det er fellesskapet som motiverer i verkstedstenkning, fordi det er der verdisettingen foregår, og resultatet beundres. Schön (1987) tar til orde for at evne til refleksjon i handling kan stimulere til videre innsats gjennom bevisstgjøring og nye strategier. Aristoteles (1999) understreker kunnskapen knyttet til ferdigheter og peker på at det er når denne kunnskapen vikles ut, at den kan hjelpe oss til å forbedre ferdighetene og øke kvaliteten på det vi gjør (Eikeland, 2014). At øvelse, terping og gjentagelse er viktige faktorer for å oppnå forbedring av ferdigheter, ligger til grunn, men både Sennett og Aristoteles peker på at dette ikke er nok for virkelig å få kvalitet i ferdighetene. Trangen til kvalitet må vekkes og ikke hemmes.

Dagens skole er preget av en sterk målekultur, der nytteperspektivet dominerer. Når dette kombineres med en sammenlignings- og rangeringskultur, kan det virke hemmende på kvalitetstenkningen, både slik at selve kvalitetsmålene endres, men også at innsatsen blir mer instrumentell. Da stimuleres tendensen til kun å lære det som skal måles (Sennett, 2009). Skolens viktige bidrag er å styrke elevens evne til å gjøre noe bra for sin egen skyld.

\section{A fremme kvalitet i ferdighetene}

Artikkelen har belyst hvordan ulike teoretiske innfallsvinkler kan berike vår forståelse av ferdighetsutvikling og hvordan vi kan motiveres til forbedring. Hovedspørsmålet i artikkelen er hvordan fremmes kvalitet $i$ utviklingen av grunnleggende ferdigheter $i$ skolesammenheng. Avslutningsvis vil vi reflektere over og antyde hvordan skolen kan utvikle en kvalitetsfremmende praksis i arbeidet med de grunnleggende ferdighetene. 


\section{Grunnleggende ferdigheter og kvalitet}

Verkstedet eller i denne sammenheng klasserommet er en sentral plass for utvikling og forbedring av grunnleggende ferdigheter. Læreren kan være både inspirator og mentor, slik gode mestre er. Innenfor verkstedstenkning er rommet, utstyret og rutinene viktige og må gjennomtenkes. Det samme gjelder hvilke normer som skal gjelde og hvordan kvalitet kan vikles ut. Gjennomsiktighet er sentralt i de åpne verkstedene, og normene for godt arbeid må klargjøres for mennesker som ikke er eksperter (Kvale, 2003). Læreren er sentral både i det å fastsette kvalitet, verdsette kvalitet og etterspørre kvalitet.

Øvelse, repetisjon og også terping vil være en del av ferdighetslæringen. Dette kan med fordel settes i et system av rutiner, ritualer og vaner, men læreren må ta hensyn til at konsentrasjonen styrkes når aktivitetene gir mening og står i en større sammenheng. Det handler også om å bli innviet i det å kunne forutsi konsekvenser av det man gjør og forestille seg resultatet. Derfor er skolen som fellesskap en god ramme for ferdighetsutvikling. Her kan man observere andres resultater og lære av andres anstrengelser. Man kan få støtte og gode råd av en mester. Man kan få lyst og motivasjon til å bli bedre. Man kan få andres blikk på egne ferdigheter og øvelser, samtale om dem og dele sine erfaringer.

Det er grunn til å understreke at målene i skolen ikke må være for snevre for nettopp frirommet til å skape noe, det å bruke fantasi og ta utradisjonelle omveier kan øke motivasjon og skape engasjement. Prøving og feiling er utviklende for elevenes ferdighetslæring. I skolen trenger elever å få erfaring med å komme videre etter å ha feilet. Gjennom å analysere og reflektere over feil kan elever utforske muligheter og motiveres til videre innsats. Dersom skolen i stor grad benytter systemer eller vurderinger som får eleven til å søke å unngå feil, kan elevenes engasjement og fantasi til å prøve og feile, reduseres. Det å våge å dvele i feilen, for å forstå hva som førte til feilen, for så å øve på å forbedre, gir mulighet for kvalitetsutvikling.

Det å sette ord på og forklare for seg selv eller andre hva en gjør eller tenker å gjøre, vil øke mulighetsrommet for ferdighetsutvikling. Det kan skjerpe elevenes blikk til å vurdere sine egne ferdigheter og oppdage hvilke anstrengelser som vil gi framgang. Skolen må legge til rette for den langsomme tid som gjør refleksjon mulig, gjerne i et slags pauserom som Eike- 
land (2014) foreslår. Refleksjon slik Schön (1987) beskriver det, kan gi den lærende strategier til forbedring og kanskje også fremme en mer fantasifull og kompleks tilnærming.

\section{Utholdenhet og stolthet}

I arbeidet med å utvikle ferdigheter er det framfor alt viktig at læreren ikke legger opp til arbeidsmåter som fremmer innstillingen, at det gjelder å bli ferdig. En hovedsak knyttet til ferdigheter er å utvikle og beholde sansen for forbedring og kvalitet. Da vil også elevens stolthet over egen utvikling bli en vedvarende drivkraft. I innlæringen vil det ofte være utholdenhet som teller, og den styrkes av mestring. Når man får til noe, holder man lenger ut også med det som kan være ensformig og gjentagende. Det er avgjørende å ha forventninger til egen innlæring. Derfor betyr læringskulturen i klasserommet mye for hvilke forventninger den enkelte elev drives av. Det henger selvsagt sammen med egen mestring, men også med lærerens vurderingskultur og hvilke verdier som blir verdsatt i klasserommet, fordi trangen til kvalitet lett kan undergraves av konkurranse. Eleven trenger lærere som evner å se hvor hun befinner seg, gi tilpasset positiv respons på innsats og som kan føre en dialog om hvordan hun kommer videre (Sennett, 2009).

Hvordan fremmes kvalitet i utvikling av ferdigheter? Klasserommet som et lærende fellesskap etter modell fra verkstedet er et velprøvd alternativ der evnen til å se kvalitet langsomt stimuleres gjennom systematisk og gjennomtenkt tilbakemeldingskultur. Der det å gjøre feil ses som en hjelp til forbedret kvalitet og mer læring. Der det blir kult å øve på noe, fordi elevene har stimulert sin forestillingsevne og fantasi til å se for seg noe virkelig strålende som kommer, og der det er rom for forskjellighet, ulike mål og ulike mestringsnivåer. Verkstedene hadde en arbeidsplass med oppgaver for de fleste, og det var både arbeidet, resultatet og opplevelsen av å gjøre noe sammen som gav mening, motivasjon og stolthet. Skolen har som en av sine mange viktige oppgaver at elevene utvikler og stadig forbedrer sine grunnleggende ferdigheter. Kanskje er det da nyttig å se for seg klasserommet som et verksted, og læreren som en reflektert mester. Et verksted som både gir rom for og stimulerer til refleksjon og samtaler om ferdigheter, slik at elevene ikke tror at det å lære de grunnleggende ferdigheter handler om å bli fort ferdig. 
En utfordring for skolen er at innholdet blir for abstrakt og generelt, og at det blir vanskelig for elevene å få øye på aktualitet. Løvlie (2013) peker på at den mening og hensikt elevene tillegger sine prestasjoner er avgjørende for deres motivasjon. Dette er det samme som mesterlæreteorien får fram gjennom sin oppmerksomhet rettet mot konsekvens av arbeid og innsats. Skolen trenger lærere som er fascinert av læreprosesser og ferdigheter, og vil være opptatt av å vise elevene hva de har lært, og hvilken betydning dette vil ha for deres framtid. Når deltagelse blir verdsatt, vil konsentrasjon og utholdenhet kunne styrkes. Lærere som forstår at ferdigheter også innehar en kunnskap, vil kunne hjelpe elever til en kraftfull refleksjon (Søndenå, 2004). Mangfoldighet er vesentlig i et verksted, fordi det ofte skaper de beste læringssammenhenger (Kvale, 2003). Møter dagens elever signaler om at mangfold og ulikhet ses som en ressurs i skolen? Om ikke så vil kanskje selve trangen til forbedring og kvalitet i ferdighetene langsomt forsvinne. Fellesskapets holdninger vil i stor grad legge forutsetninger for den enkelte elevs innstilling og ambisjoner. Derfor er ikke kvalitetsutvikling av ferdigheter kun en aktivitet inne i klasserommet. Det handler også om hvordan storsamfunnet ser på mangfold, ferdigheter og prestasjon.

\section{Avsluttende bemerkning}

Med bakgrunn i denne litteraturstudien understrekes det at klasserommet som et lærende fellesskap, ivaretas og fremmes gjennom lærere som tydelig gir både innsats og resultat verdi og som understreker læring som en fellesaktivitet der elever kan få observere hverandre og lære av hverandre. Vi har pekt på at kvalitet i grunnleggende ferdigheter kan stimuleres gjennom refleksjon og en systematisk og gjennomtenkt tilbakemeldingskultur. Men det vil samtidig være av betydning at det å feile ses på som en hjelp til mer læring og ikke minst at det $\mathrm{i}$ klassefellesskapet både gis rom for og verdsettes forskjellighet, ulike mål og ulike mestringsnivåer. Ferdigheter er både å gjøre og å skape. Sentralt er derfor også evnen til å forestille seg. Forestillingsevne kan fremmes gjennom å leke med muligheter og forfølge egne ideer. Terping og øvelse når det gjelder grunnleggende ferdigheter må derfor settes inn $\mathrm{i}$ et skapende mulighetsrom. For å styrke en kvalitetsfremmende praksis i 
arbeidet med de grunnleggende ferdighetene, framheves derfor en bred tilnærming slik at det ikke bare handler om å øve inn og bli ferdig. Viktig er det at opplæringen gir anledning til å være fri og skapende ut fra egne forutsetninger, samtidig som den hjelper elevene til å utvikle sitt eget skjerpende og kritiske blikk som drivkraft til forbedring.

\section{Referanseliste}

Aristoteles. (1999). Den nikomakiske etikk. Oslo: Bokklubben Dagens Bøker. Brunstad, P.O. (2007). Faglig klokskap mer enn kunnskap og ferdigheter. Pacem 10( 2) 59-70.

Dale, E.L. (1989). Pedagogisk profesjonalitet. Om pedagogikkens identitet og anvendelse. Aurskog: Gyldendal Norsk Forlag.

Dale, E.L. \& Øzerk, K. (2009). Underveisanalyser av Kunnskapsløftets intensjoner og forutsetninger. Delrapport nr. 2. Oslo: Universitetet i Oslo.

Dale, E.L., Engelsen, B.U. \& Karseth, B. (2011). Kunnskapsloftets intensjoner, forutsetninger og operasjonaliseringer: En analyse av en lareplanreform. Sluttrapport. Oslo: Universitetet i Oslo.

Eikeland, O. (2014). Bricolage? En kunnskapsteoretisk drøfting av utviklingsarbeidets former og egenart. I: G. Bjørke, H, Jarning \& O. Eikeland. Ny praksis - ny kunnskap; om utviklingsarbeid som sjanger. Oslo: ABM-media.

Gjerustad, C., Waagene, E. \& Salvanes, K.V. (2015). Spørsmål til Skole-Norge hosten 2014 - Resultater og analyser fra Utdanningsdirektoratets spørreundersøkelse blant skoler og skoleeiere (NIFU-rapport nr. 3/2015). Oslo: NIFU.

Hertzberg, F. (2012). Grunnleggende ferdigheter - hva vet vi om skolenes praksis. Trondheim: Akademika.

Hodgson, J., Rønning, W., Skogvold, A. S. \& Tomlinson, P. (2010). På vei fra lareplan til klasserom. Om lareres fortolkning, planlegging og syn $p a$ LK06. NF-rapport nr. 3/2010 Bodø: Nordlandsforskning.

Hodgson, J., Rønning, W. \& Tomlinson, P. (2012). Sammenhengen mellom undervisning og laring. En studie av lareres praksis og deres tenkning under Kunnskapsløftet. (SMUL). 
Illeris, K. (2000). Laring - aktuell laringsteori i spenningsfeltet mellom Piaget Freud og Marx. Oslo: Gyldendal akademisk.

Kvale, S. (2003). En præmoderne mesterlære i et postmoderne samfund? I K. Nielsen \& S. Kvale. Praktikkens laringslandskab. At lare gennem arbejde. København: Akademisk forlag.

Lauvås, P. \& Handal, G. (2000). Veiledning og praktisk yrkesteori. Oslo: J. W. Cappelens Forlag.

Lave, J. \& Wenger, E. (2003). Situeret laring og andre tekster. København: Hans Reitzels Forlag.

Nielsen, K. \& Kvale, S. (2003). Praktikkens laringslandskab. At lare gennem arbejde. København: Akademisk forlag.

Nielsen, K. \& Kvale, S. (Red.), (1999). Mesterlare. Oslo: Ad Notam Gyldendal.

NOU 2015:8 (2015). Fremtidens skole. Oslo: Kunnskapsdepartementet.

Nussbaum, M.C. (1995). Känslans skärpa, tankens inlevelse. Stockholm: Brutus Östlings Bokförlag.

Ottesen, E. \& Møller, J. (Red.), (2010). Underveis, men i svart ulikt tempo. Et blikk inn i ti skoler etter tre år med Kunnskapsløftet. Rapport 37/2010. Oslo: NIFU STEP/Universitetet i Oslo.

Polanyi, M. (1966, 2000). Den tause dimensjonen. Oslo: Spartacus forlag.

Ramirez, J. (1995). Skapande mening. En begreppsgenealogisk undersökning om rationalitet, vetenskap och planering. Nordiska instituttet för samhällsplanering. Doktorgradsavhandling. Stockholm: Nordplan.

Rødnes, K.A. \& Gilje, Ø. (2018). Ti år med grunnleggende ferdigheter hva vet vi, og hvor går vi? Norsk Pedagogisk Tidsskrift 02(03) 201-213.

Schön, D.A. (1983). The reflective practitioner. How professionals think in action. New York: Basic Books, Inc., Publishers.

Schön, D.A. (1987). Educating the reflective practitioner. San Francisco: Jossey-Bass Ink., Publishers.

Sennett, R. (2009). Håndvarkeren. Arbejdets kulturhistorie: Hånd og ånd. Viborg: Forlaget Hovedland.

Sigurjonsson, G. (2003). Fra mesterlære til skolastisk læring. I K. Nielsen \& S. Kvale Praktikkens laringslandskab. At lare gennem arbejde. København: Akademisk forlag. 
St. Meld. 30 (2003-2004). Kultur for laring. Oslo: Utdanningsdepartementet.

St. Meld. 28 (2015-2016). Fag-Fordypning-Forståelse. Oslo: Kunnskapsdepartementet.

Søndenå, K. (2004). Kraftfull refleksjon i lererutdanningen. Oslo: Abstrakt forlag.

Utdanningsdirektoratet. (2006). Lareplanverket for Kunnskapsløftet. Midlertidig utgave. Oslo: Utdanningsdirektoratet.

Utdanningsdirektoratet. (2012). Rammeverk for grunnleggende ferdigheter. Oslo: Kunnskapsdepartementet.

Utdanningsdirektoratet. (2019). Laring og trivsel: Nye lareplaner. https:/www.udir.no/laring-og-trivsel/lareplanverket/fagfornyelsen/nyelareplaner-i-skolen/ 